\title{
ABNORMALITIES OF MUSCLE PROTEIN METABOLISM IN MICE WITH MUSCULAR DYSTROPHY*
}

\author{
By JACQUES KRUH, JEAN-CLAUDE DREYFUS, GEORGES SCHAPIRA AND \\ GEORGE O. GEY, JR. $\dagger$ WITH THE TECHNICAL ASSISTANCE OF \\ MRS. TIKHONITZKY

\begin{abstract}
(From the Laboratoire de Recherches de Biochimie Médicale, Hôpital des Enfants Malades, Paris, France)
\end{abstract}

(Submitted for publication January 7, 1960; accepted March 10, 1960)

The discovery of a myopathic mutation in a colony of strain 129 mice $(1,2)$ provides an opportunity for the study of possible abnormalities in the metabolism of muscle proteins with the use of labeled amino acids. Cell proteins may show various kinds of behavior. Some of them are constantly being renewed, either secreted, like digestive enzymes or serum albumin from the liver, or subjected to a molecular turnover, as in the case of muscle aldolase and probably all the water-extractable muscle proteins. The other proteins apparently stay unchanged during the life span of the cell, as in the case of hemoglobin in red blood cells (3), of collagen in the rat (4), or of myosin in the myofibril, a subcellular unit (5, 6). We have previously shown in the rat that myosin has a very slow renewal and that its metabolic behavior permits the measurement of the life span of the myofibril, which is close to 30 days in the rat. If, after the injection of a radioactive amino acid, the radioactivity of the protein is plotted against time, the first kind of protein shows an exponential decline, but hemoglobin and myosin show a plateau followed by a rapid decline. These two kinds of curves are combined if the protein is slowly renewed and belongs to a cell or part of a cell with a relatively short life span.

In this work we have compared the metabolism of myosin and water-extractable muscle proteins in dystrophic mice, in their normal litter mates, and in another normal strain of mice. We have not prepared pure aldolase, which would have required too large a number of animals, but we

\footnotetext{
* Supported by grants from the Caisse Nationale de Sécurité Sociale, France, the Institut National d'Hygiène, France, the Muscular Dystrophy Associations of America, Inc., and by a research grant (no. RG-6016) from the United States Public Health Service, Division of General Medical Sciences, Bethesda, Md.

$\dagger$ Present address: Clare College, Cambridge, England.
}

have previously seen that the total water-extractable proteins have the same gross behavior as aldolase $(5,6)$.

\section{METHODS}

Animals. We have used normal mice strain RAP, dystrophic mice, and their normal litter mate strain 129, which were obtained from the Roscoe B. Jackson Memorial Laboratory, where they have been isolated by Michelson, Stevens and co-workers $(1,2)$. The muscular dystrophy of these mice is linked to an autosomal recessive gene, the disease appearing only in the homozygotic mice. These mice have a generalized muscular atrophy, and the microscopic appearance of the muscle tissue is characteristic of progressive muscular dystrophy of man. The mice, whose weight varied between 10 and $16 \mathrm{~g}$, received a diet containing 24 per cent protein. They were fasted 24 hours before and 8 hours after the injection of the radioactive amino acid. They were injected intraperitoneally with glycine-2- $\mathrm{C}^{14}, 1 \mu \mathrm{C}$ per $10 \mathrm{~g}$ of body weight. For each protein preparation 3 to 4 normal mice or 4 to 5 dystrophic mice were pooled. The number of experiments was limited by the difficulty in obtaining the mice and by their short life expectancy. None of the mice lost weight during the experiments.

Preparation of the proteins. The mice were killed by bleeding. Muscles were ground and the water-extractable proteins and free glycine were extracted with twicedistilled water. The myosin was extracted with potassium iodide according to Szent-Györgyi (7) and purified twice by precipitation by dilution, and by redissolution in a buffered potassium chloride solution. The purity was checked by moving boundary electrophoresis which showed one symmetrical peak (Figure 1). The absence of actomyosin was checked in each experiment by the measurement of the viscosity before and after the addition of adenosine triphosphate. The water-extractable proteins were precipitated by adding half a volume of 20 per cent trichloroacetic acid to the muscle extract.

Free glycine of muscle. The free glycine of muscle was obtained from the supernatant of the trichloroacetic acid precipitation of the water extract. This solution was evaporated to dryness in vacuo and the trichloroacetic acid was extracted with ether. After treatment with dinitrofluorobenzene, the dinitrophenylglycine (DNPglycine) was isolated on a celite column, according to 


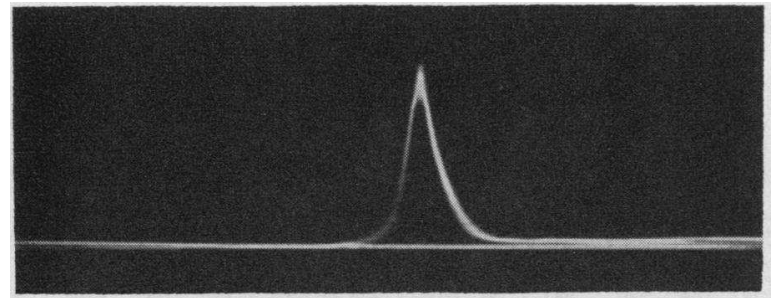

Fig. 1. Electrophoresis of mouse myosin. $1.19 \mathrm{v}$ per cm; 22 hours, 40 minutes. Phosphate buffer $\mu=0.35$, $\mathrm{pH} 7.1$.

the technique of Perrone (8), as modified by Padieu (9) and Kruh and associates (10). Its purity was systematically checked by paper chromatography according to Biserte and Osteux (11).

Measurement of radioactivity. Myosin, like the watersoluble proteins, was precipitated by half a volume of 20 per cent trichloroacetic acid. The precipitates were washed twice with 7 per cent trichloroacetic acid, twice with acetone, and once with ether. The dry proteins were ground into a fine powder in a Potter apparatus and in an agate mortar, and then spread in a regular layer of $40 \mathrm{mg}$ protein on copper planchets of $1.52 \mathrm{~cm}^{2}$ surface, which constitutes infinite thickness. The DNP-glycine was dissolved in methanol and estimation was made in a Beckman DU spectrophotometer at $360 \mathrm{~m} \mu$ on an aliquot, after dilution in 2 per cent $\mathrm{NaHCO}_{3}$. The radioactivity was measured on another aliquot after heat dessication on a copper planchet of $2.85 \mathrm{~cm}^{2}$ surface in which a lens paper was fixed with silicone grease. A Geiger-Müller counter with a thin end-window was used, and the specific activity of DNP-glycine was expressed in counts per minute per millimole; the correction for thickness was made. The determinations were carried out with a statistical error of less than \pm 2 per cent.

\section{RESULTS}

\section{Normal mice (strain $R A P$ )}

Myosin (Figure 2). Two series of experiments involving 40 mice showed a constancy of radioactivity between the second and twentieth days with a mean value of $30 \mathrm{cpm} \pm \mathrm{SD}=2$. Then the radioactivity decreased and remained constant until the thirty-eighth day at a level of $19 \pm \mathrm{SD}=$ 2.5. ${ }^{1}$

Water-extractable proteins (Figure 2). The radioactivity of the water-extractable proteins was much higher than that of myosin on the second day, then it decreased exponentially.

$$
1 \mathrm{SD}=\sqrt{\frac{\left(\mathrm{x}-\mathrm{x}_{0}\right)^{2}}{\mathrm{n}-1}}
$$

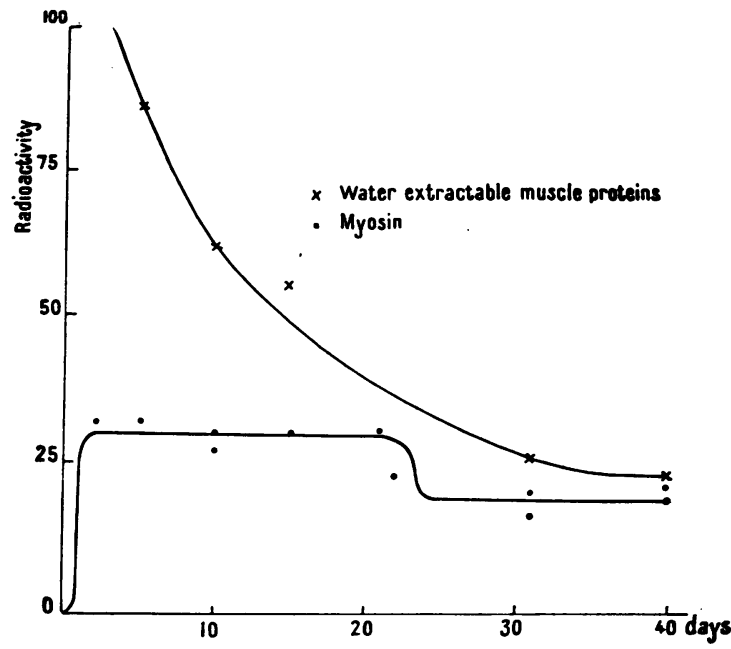

Fig. 2. Radioactivity of Myosin AND WATER-EXTRACTABLE PROTEINS, MOUSE STRAIN RAP. The radioactivities are measured on $40 \mathrm{mg}$ of protein on planchets of $1.52 \mathrm{~cm}^{2}$ surface and expressed in counts per minute.

Free glycine of muscle (Figure 5). The specific activity of free glycine decreased exponentially from the second day.

\section{Dystrophic mice and normal litter mate (strain 129)}

The mice were killed at the sixth hour and on the first, second, fourth, sixth and fifteenth days after the injection of $\mathrm{C}^{14}$-glycine.

Myosin (Figure 3). In the normal litter mate the radioactivity was constant between the first and the fifteenth days. In the dystrophic mice the radioactivity increased until the fourth day, when it was twice as high as that in the normal mice. After the sixth day it decreased, and on the fifteenth day the value of the radioactivity was close to that of the normal mice.

Water-extractable proteins (Figure 4). In normal as well as in dystrophic mice the radioactivity increased until the twenty-fourth hour and then decreased, but the variation as a function of time was much larger in the dystrophic than in the normal mice. The ratio of the radioactivities was 2 in the twenty-fourth hour and 1.3 on the fifteenth day.

Free glycine of muscle (Figure 5). The specific activity of free glycine decreased exponentially until the first or second day, then the slope of the semilogarithmic curve changed. The de- 


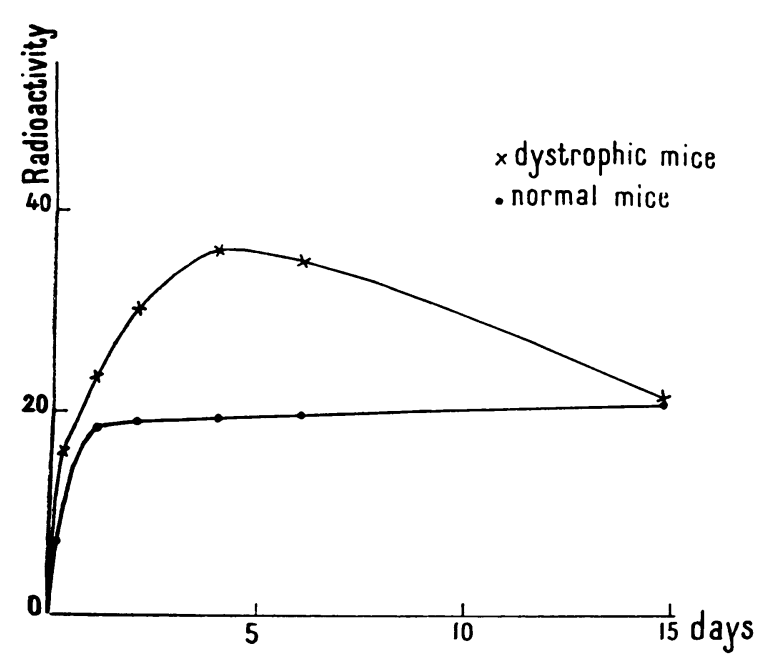

Fig. 3. Radioactivity of myosin. The radioactivities are measured on $40 \mathrm{mg}$ of protein on planchets of $1.52 \mathrm{~cm}^{2}$ surface and expressed in counts per minute.

crease, however, remained exponential until the fifteenth day, confirming the results previously obtained (12). The curves of the specific activity were approximately the same in the normal and in the dystrophic mice.

\section{DISCUSSION}

This work on normal mice confirms the results obtained with rats $(5,6)$. Myosin does not show any apparent turnover in mice on a normal protein diet. The constancy of the radioactivity seems to substantiate a life span of the myofibrils of 30 days in the rat, and 20 days in the mouse, according to the present work. After the decline of the specific activity at about the twenty-second day, the radioactivity of the myosin presents a second plateau which could be easily explained by the re-utilization of the labeled amino acids liberated by the degradation of the radioactive myosin; such a re-utilization has been shown to occur with radioactive iron in hemoglobin. Water-extractable proteins show an exponential decrease, which means that the sarcoplasmic proteins are subject to turnover.

The acceleration of protein metabolism in dystrophic mice has been demonstrated by Simon, Lessell, Gross and Milhorat (13). These authors injected $\mathrm{C}^{14}$-leucine into mice and observed a faster incorporation of the amino acids into the proteins and a faster rate of disappearance from the proteins in the dystrophic animals. The more recent knowledge of the myofibrils' life span and the isolation of pure myosin provide some information on the localization of the biochemical lesion. The lesion may be localized at a molecular, a subcellular, or a cellular level. The difference in behavior cannot be explained by a modification of the permeability of the muscle cell to glycine, since we have not found any significant difference between the specific activity of free glycine in normal and in dystrophic mice. Nevertheless, a difference of penetration of radioactive glycine into the cells in the first hours after the injection cannot be excluded. It would explain the more rapid increase of radioactivity but not the more rapid subsequent decrease.

At a molecular level results could be partly explained by an acceleration of muscle protein turnover according to the hypothesis of Simon and coworkers (13). We have previously shown that in rats submitted to a high protein diet, myosin shows a slow turnover which, in rats submitted to a standard diet, was disguised because of the reutilization of radioactive glycine. In rats submitted to such a diet the radioactivity of myosin declined progressively. In pathological conditions, with accelerated turnover of myosin, the turnover can become apparent even with the standard diet. The finding of an acceleration of the turnover of the water-extractable muscle proteins is in keeping with a general acceleration of the turnover of

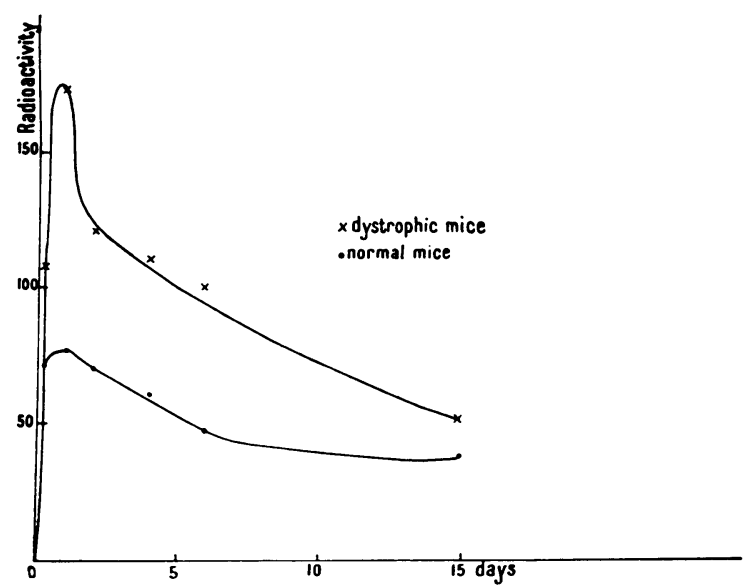

Fig. 4. Radioactivity of WATER-extractable PRoTEINS. The radioactivities are measured on $40 \mathrm{mg}$ of protein on planchets of $1.52 \mathrm{~cm}^{2}$ surface and expressed in counts per minute. 


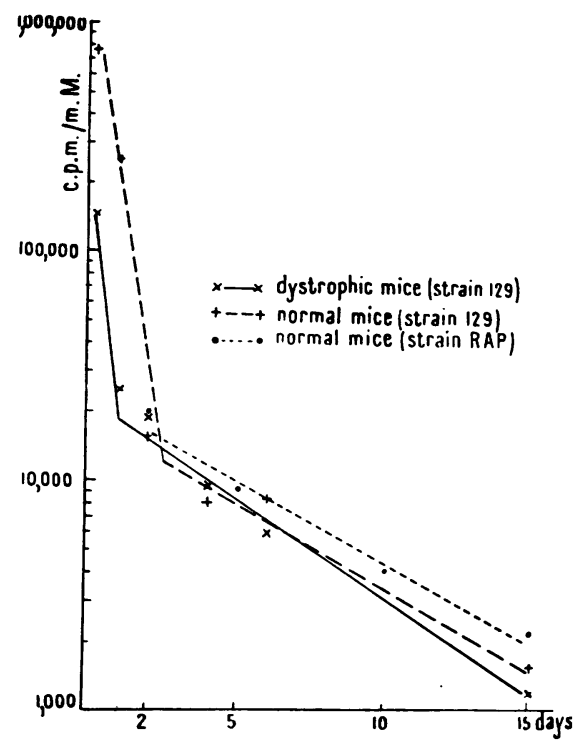

Fig. 5. Specific ACtivity of Free glycine of muscle. The specific activities are expressed in counts per minute per millimole of DNP-glycine.

all the muscle proteins. However, an acceleration of the turnover should lead to a faster rate of incorporation of the labeled glycine into myosin. Figure 3 shows that in dystrophic mice there is a rise in the radioactivity of myosin during the first four days instead of for one day as in normal mice. A possible explanation of this discrepancy might be the release of amino acids derived from the degradation of radioactive water-extractable proteins and their utilization inside the cell for the synthesis of new myosin molecules.

At the subcellular level, these results could be interpreted by a shorter life span or by the $a b-$ sence of a life span of myofibrils, as in the case of the red blood cells in hemolytic and sickle cell anemia. This hypothesis, however, would only explain the acceleration of the myosin turnover. Due to the relatively small number of experiments, it would be impossible to make any distinction between an absence of a life span of the myofibrils and a shorter life span of these particles which would involve a short plateau.

At the cellular level, the results could be explained by a shorter life span of the muscle cells, with an acceleration of the formation of new cells. Michelson and associates (1) have seen, in dystrophic mice, division of muscle fibers into two or three parts. A more detailed study is still needed since the life span of the muscle cell has not yet been established. It seems that the results presented here could be explained by an acceleration of the turnover of muscle proteins or by a shorter life span of the muscle cells, or by both hypotheses. It is not possible at present to determine which of these two hypotheses may be correct, but the first seems more likely. An acceleration of the turnover of the muscle proteins is probably the most important abnormality of muscle protein metabolism in dystrophic mice. It would be important to know whether or not the same abnormality occurs in human muscular dystrophy.

\section{SUM MARY}

The authors have studied the metabolism of myosin and water-extractable proteins in normal mice and in mice with hereditary muscular dystrophy.

1. In normal mice the constancy of the radioactivity of myosin favors the interpretation of a life span for the myofibrils of approximately 20 days. The radioactivity of the water-extractable proteins decreases exponentially, due to a turnover of these proteins. These results are in agreement with those obtained previously in rats.

2. In dystrophic mice the radioactivity of myosin increases for the first four days, then decreases without a plateau. The turnover of the water-extractable muscle proteins is highly accelerated. These results can be interpreted as representing a shorter life span of the muscle cell, or of a part of the cell or, more likely, as an acceleration of the turnover of the muscle proteins.

\section{REFERENCES}

1. Michelson, A. M., Russell, E. S., and Harman, P. J. Dystrophia muscularis, a hereditary primary myopathy in the house mouse. Proc. nat. Acad. Sci. (Wash.) 1955, 41, 1079.

2. Stevens, L. C., Russell, E. S., and Southard, J. L. Evidence on inheritance of muscular dystrophy in an inbred strain of mice using ovarian transplantation. Proc. Soc. exp. Biol. (N. Y.) 1957, 95, 161.

3. Shemin, D., and Rittenberg, D. Life span of human red blood cell. J. biol. Chem. 1946, 166, 627.

4. Neuberger, A., Perrone, J. C., and Slack, H. G. B. The relative metabolic inertia of tendon collagen in the rat. Biochem. J. 1951, 49, 199. 
5. Dreyfus, J. C., Kruh, J., and Schapira, G. Metabolism of myosin and life time of myofibrils. Biochem. J. In press.

6. Dreyfus, J. C., Kruh, J., and Schapira, G. Metabolisme des protéines musculaires in International Conference on Radioisotopes in Scientific Research. New York, Pergamon Press, 1958, vol. III, p. 386.

7. Szent-Györgyi, A. G. A new method for the preparation of actin. J. biol. Chem. 1951, 192, 361.

8. Perrone, J. C. Separation of amino-acids as dinitrophenyl derivatives. Nature (Lond.) 1951, 167, 513.

9. Padieu, P. Biosynthèse des protéines musculaires et section du nerf moteur. Bull. Soc. Chim. biol. (Paris) 1959, 41, 57.
10. Kruh, J., Dreyfus, J. C., Schapira, G., and Padieu, P. Non-uniform incorporation of glycine-2- ${ }^{14}$ into rabbit hemoglobin in vivo and in vitro. $\mathrm{J}$. biol. Chem. 1957, 228, 113.

11. Biserte, G., and Osteux, R. La chromatographie de partage sur papier de dinitrophényl-aminoacides. Bull. Soc. Chim. biol. (Paris) 1951, 33, 50.

12. Schapira, G., Dreyfus, J. C., Kruh, J., Labie, D., and Padieu, P. Sur l'absence d'un pool métabolique unique du glycocolle libre des tissus. Bull. Soc. Chim. biol. (Paris) 1959, 41, 469.

13. Simon, E. J., Lessell, I., Gross, C. S., and Milhorat, A. T. Amino-acid incorporation into muscle and liver proteins of mice with hereditary muscular dystrophy. Fed. Proc. 1958, 17, 311. 